\title{
Radioimmunoassay for the determination of glycated haemoglobin
}

\author{
Z. Makita, H. Nakayama, S. Taneda, M. Kato, Y.Kuroda, S. Aoki, K. Misawa and S. Nakagawa \\ The 2nd Department of Medicine, Hokkaido University School of Medicine, Sapporo, Japan
}

\begin{abstract}
Summary. A competitive radioimmunoassay for the quantitative determination of glycated haemoglobin was developed. The antiserum, obtained by immunizing guinea pigs with reduced glycated human albumin, was capable of identifying and quantitating the glucitollysine residues of glycated $\mathrm{Hb}$ after reduction with sodium borohydride. To simplify the sample preparation we introduced trichloroacetic acid precipitation to remove unreacted sodium borohydride instead of using dialysis or gel filtration. Using this procedure, our radioimmunoassay became relatively simple and provided satisfactory within- and between-run (1.3-2.8\% and $1.9-5.4 \%$ coefficient of variation, respectively). The radioimmunoassay method was compared to the measurement of $\mathrm{HbA}_{l c}$ by high performance liquid chromatography which is the most widely used method for quantitating glycated $\mathrm{Hb}$. For this purpose glycated $\mathrm{Hb}$ was measured in normal glucose tolerance, impaired glucose tolerance, and diabetes mellitus groups based on WHO criteria. Both assays were able to discriminate between the normal and diabetic
\end{abstract}

groups. In addition, while the determination of glycated $\mathrm{Hb}$ by the radioimmunoassay method was able to clearly discriminate between the normal and impaired glucose tolerance groups, the determination of $\mathrm{Hb}_{\mathrm{fc}}$ by the high performance liquid chromatography method failed to discriminate between these two groups. Moreover, 15 of the 20 impaired glucose tolerance patients exceeded the upper normal range (mean normal values $+2 \mathrm{SD}$ ) in radioimmunoassay. But all 20 patients with impaired glucose tolerance were within the upper normal range in $\mathrm{HbA}_{I c}$ values.

These results demonstrate that the measurement of glycated $\mathrm{Hb}$ by radioimmunoassay is more sensitive than the measurement of $\mathrm{HbA}_{t c}$ by high performance liquid chromatography since it can discriminate between the normal and impaired glucose tolerance groups.

Key words: Radioimmunoassay, glycation, $\mathrm{HbA}_{l c}$, glucose, glucitollysine
Glycated $\mathrm{Hb}$ is being used with increasing frequency to monitor long-term blood glucose control in diabetes mellitus [1-5]. The test of glycated $\mathrm{Hb}$ provides an accurate index of the mean concentration of blood glucose during the preceding two or three months, complementing more traditional measures of glucose control, such as glucose testing in urine and blood. A variety of methods have been described for the determination of glycated $\mathrm{Hb}$, but many of them have serious pitfalls $[6,7]$. The clinical utility of glycated $\mathrm{Hb}$ measurement will not achieve its full potential until appropriate references, standards, and degrees of accuracy and precision of these measurements are agreed upon.

$\mathrm{HbA}_{1 c}$ is identical to $\mathrm{HbA}_{0}$ except that in $\mathrm{HbA}_{l c}$ glucose is linked to the amino-terminal valine residue of the $\beta$ chain [8]. Modification of $\mathrm{Hb}$ with glucose confers a change in charge of the $\mathrm{Hb}$ molecule. Most methods for quantitating glycated $\mathrm{Hb}$ utilize this charge difference to separate the $\mathrm{HbA}_{i c}$ from $\mathrm{HbA}_{\vartheta}$ by ion-exchange chromatography or high performance liquid chromatography (HPLC) [7]. The amount of $\mathrm{HbA}_{l c}$ is then expressed as a percentage of total $\mathrm{Hb}$. Glucose can also condense with the $\varepsilon$-amino groups of lysine residues, and the amount of $\mathrm{Hb}$ modified at these sites, which is increased in erythrocytes from diabetic patients [9], is not always quantitatable by ion-exchange chromatography or HPLC.

We recently reported an enzyme-linked immunosorbent assay (ELISA) for detecting glycated serum proteins and a radioimmunoassay (RIA) for glycated serum albumin using an antiserum which was obtained by immunizing guinea pigs with reduced glycated human albumin $[10,11]$. This antiserum contained antibodies which recognize glucitollysine epitopes in not only reduced glycated albumin and glycated plasma protein but also reduced glycated $\mathrm{Hb}$. In this paper; we developed an RIA for glycated $\mathrm{Hb}$ using the antiserum 


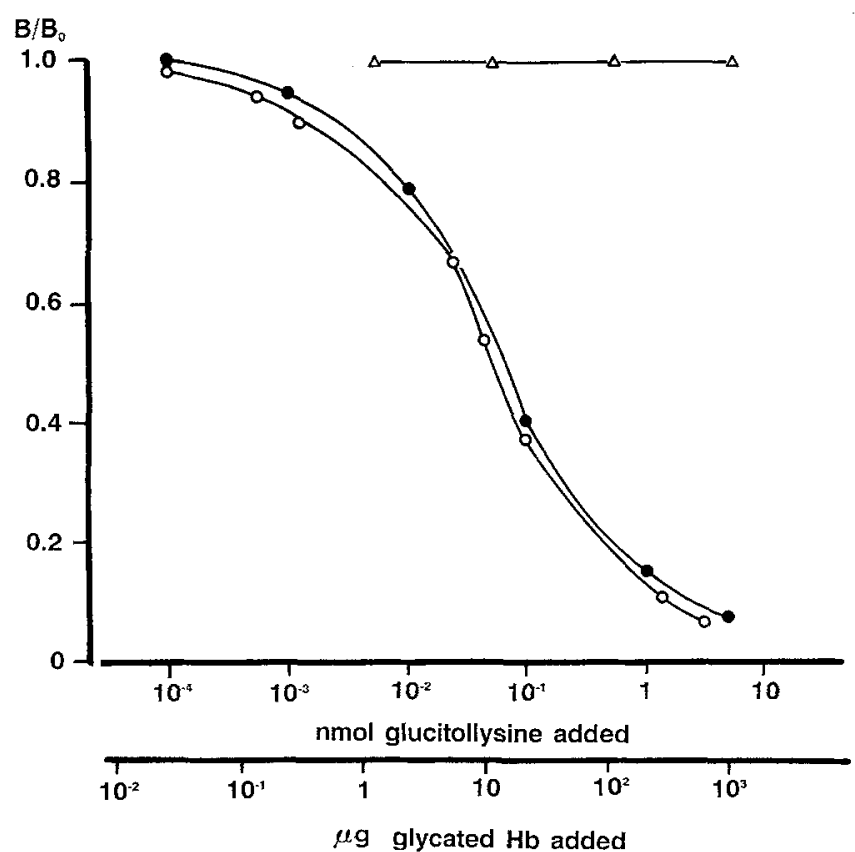

Fig.1. Competition of glucitollysine with reduced glycated $\mathrm{Hb}$ and non-reduced glycated $\mathrm{Hb}$ which was prepared from a diabetic patient. Antiserum, at final dilution of 1:500, was added in the presence of glucitollysine, reduced glycated $\mathrm{Hb}$, or non-reduced glycated $\mathrm{Hb}$. Data were expressed as $\mathrm{B} / \mathrm{B}_{0}$, in which $\mathrm{B}$ represents the count of ${ }^{125} \mathrm{I}$ labelled reduced glycated HSA bound in the presence of competitors, and $\mathrm{B}_{0}$ that bound in the absence of competitor. Glucitollysine $(\bullet)$, reduced glycated $\mathrm{Hb}(\mathrm{o})$, non-reduced glycated $\mathrm{Hb}(\Delta)$. nmol glucitollysine added refers to glucitollysine $(\bullet)$. $\mu$ g glycated $\mathrm{Hb}$ added refers to reduced $(\mathrm{o})$ and non-reduced $(\Delta)$ glycated $\mathrm{Hb}$

and present a comparison of this assay with $\mathrm{HbA}_{l c}$ measured by the HPLC method with respect to their discriminative power.

\section{Materials and methods}

\section{Reagents}

Human serum albumin (HSA), human haemoglobin, CBZ-L-lysine, sodium borohydride $\left(\mathrm{NaBH}_{4}\right)$ and bovine gamma globulin (G-5009) were obtained from Sigma Chemical Co. (St. Louis, Mo., USA). Bovine serum albumin (BSA,A-6003) was from Calbiochem Behring Co. (La Jolla, Calif., USA). Bio-Rex 70 and Affi-Gel 15 were from Bio-Rad Laboratories (Richmond, Calif., USA). Glyco-Gel B was from Pierce Chemical Co. (Rockford, Ill., USA). The ${ }^{125}$ Iradioiodination system was from New England Nuclear (Boston, Mass., USA). All other reagents were of the highest grade commercially available.

\section{Preparation of glycated $\mathrm{HSA}$, glycated $\mathrm{Hb}$ and glucitollysine}

Reduced glycated HSA, reduced glycated $\mathrm{Hb}$, non-reduced nonglycated HSA and non-reduced non-glycated Hb were prepared as described previously [10]. The extent of glycation of each sample was assessed by amino acid analysis as described by Trüeb et al. [12]. The percentage of lysine residue glycation was $62 \%$ in reduced glycated $\mathrm{HSA}$ and $35 \%$ in the reduced glycated $\mathrm{Hb}$. Glucitollysine was synthesized by the method of Trüeb et al. [12]. Glucitolvaline was synthesized by the method of Schwarz and Gray [13].

\section{Immunization and preparation of antiserum to glucitollysine}

Male guinea pigs were immunized with reduced glycated HSA as described previously [10]. To remove cross-reactivity with native HSA, $1 \mathrm{ml}$ of the immunized guinea pig serum was purified on an AffiGel 15 column coupled to native $H . S A$, eluted with $0.1 \mathrm{~mol} / \mathrm{l}$ sodium. phosphate buffer, $\mathrm{pH} 8.0$, and stored at $-70^{\circ} \mathrm{C}$.

\section{Radiolabelling of HSA}

Reduced glycated HSA and native HSA were iodinated by solidphase lactoperoxidase using radioiodination system [11]. The free iodide was separated from the labelled protein by chromatography on Sephadex G-25, PD 10. The specific activities of the labelled proteins were about $5000 \mathrm{cpm} / \mathrm{ng}$.

\section{Chromatography on Bio-Rex 70}

Erythrocyte haemolysates were prepared after overnight $0.9 \%$ $\mathrm{NaCl}$ incubation as described by Nathan et al. [14]. The haemolysates from a diabetic patient and a normal subject were then analysed on a Bio-Rex 70 column $(1 \times 30 \mathrm{~cm})$ according to the method of Abraham et al. [15].

\section{Subjects and sample preparation}

Following a $75 \mathrm{~g}$ oral glucose tolerance test, subjects were classified as having normal glucose tolerance $(\mathrm{N})(n=30$, age range 1876 years), diabetes mellitus ( $n=30,36-75$ years), and impaired glucose tolerance (IGT) $(n=20,40-76$ years) according to WHO criteria [16]. Whole blood was collected in EDTA and centrifuged at $4^{\circ} \mathrm{C}$, $1500 \mathrm{~g}$, for $10 \mathrm{~min}$. Erythrocytes were washed three times with isotonic saline $(0.9 \%)$, then diluted $1: 20$, and incubated overnight at $22^{\circ} \mathrm{C}$ to remove the labile aldimine fraction. After centrifugation at $4^{\circ} \mathrm{C}, 1500 \mathrm{~g}$, for $10 \mathrm{~min}$, the saline supernatant was removed and the erythrocytes were haemolyzed in 3 volume of distilled-deionized water and glycolipids were extracted with 3 volume of toluene. Separation of the haemolysate from toluene, glycolipids, and cell ghosts was accomplished by centrifugation at $1500 \mathrm{~g}$ for $30 \mathrm{~min}$. An aliquot of each sample was reduced at $37^{\circ} \mathrm{C}$ for $30 \mathrm{~min}$ with $50 \mathrm{mmol} / \mathrm{l}$ $\mathrm{NaBH}_{4}$. To remove unreacted $\mathrm{NaBH}_{4}$ and to stop the reduction, glycated $\mathrm{Hb}$ was precipitated by addition of ice-cold trichloroacetic acid (TCA, $6 \%$ final concentration), followed by centrifugation at $4^{\circ} \mathrm{C}$, $3000 \mathrm{~g}$, for $30 \mathrm{~min}$. The supernatant was discarded by aspiration and the sedimented protein dissolved in $0.05 \mathrm{~N} \mathrm{NaOH}$ (TCA-NaOH treatment). The $\mathrm{pH}$ of this solution was adjusted to $\mathrm{pH} 7.4$ using $0.2 \mathrm{~mol} / 1$ potassium phosphate- $\mathrm{NaOH}$ buffer. Reduced glycated $\mathrm{Hb}$, appropriately diluted was also prepared by exhaustive dialysis against phosphate-buffered saline, $\mathrm{pH} 7.2$ after $\mathrm{NaBH}_{4}$ reduction instead of TCA-NaOH treatment as described above.

\section{Assay of glycated $\mathrm{Hb}$}

Test samples $(100 \mu \mathrm{l})$ which were reduced with $\mathrm{NaBH}_{4}$ and treated with TCA-NaOH as mentioned before were incubated with $200 \mu \mathrm{l}$ of $0.2 \mathrm{~mol} / 1$ potassium phosphate- $\mathrm{NaOH}$ buffer, $\mathrm{pH} 7.4$ containing $0.25 \% \mathrm{BSA}, 100 \mu \mathrm{l}$ of antiserum [final dilution 1:500 at $50 \%$ inhibition $\left.\left(\mathrm{B} / \mathrm{B}_{0}\right)\right]$, and $100 \mu \mathrm{l}$ of ${ }^{125} \mathrm{I}$-labelled reduced glycated HSA, diluted to about $20,000 \mathrm{cpm}$, in polystyrene tubes for $24 \mathrm{~h}$ at $4^{\circ} \mathrm{C}$. After the incubation, bound tracer was precipitated by adding $10 \mu \mathrm{l}$ $(1 \mathrm{mg}$ ) of bovine gamma globulin and $500 \mu \mathrm{l}$ of ice-cold $25 \%$ polyethylene glycol 6000 containing $0.1 \%$ Tween 20 and centrifuging at $3000 \mathrm{rev} / \mathrm{min}$ for $45 \mathrm{~min}$ at $4^{\circ} \mathrm{C}$. The radioactivity of the precipitate was counted in an LKB 1282 gamma counter. Glucitollysine at 0.005 $5 \mathrm{nmol} / 100 \mu \mathrm{l}$ was used as the standard. The $\mathrm{Hb}$ protein concentrations were determined according to Lowry et al. [18]. 


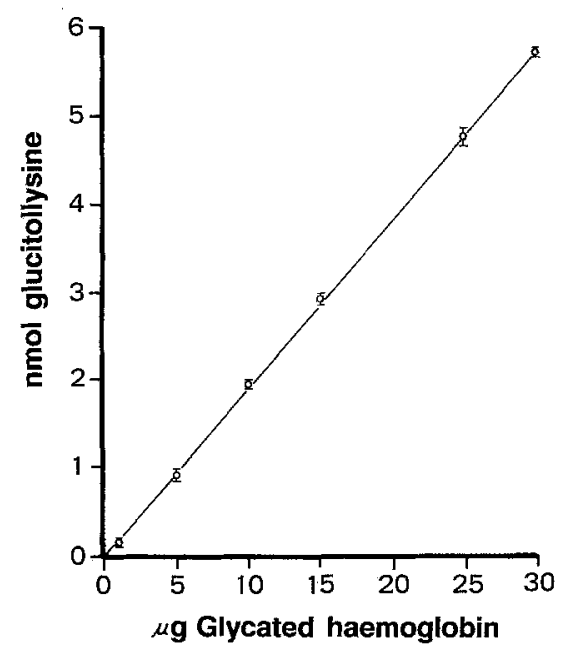

Fig. 2. The linear range of the RIA. Reduced glycated $\mathrm{Hb}$ with a high concentration of glucitollysine was obtained by using an affinity chromatography. A series of six solutions was prepared by diluting the assay buffer. Points and bars are mean \pm SD for four determinations

\section{$H b A_{1 \mathrm{c}}$ determination by $H P L C$}

Determination of $\mathrm{HbA}_{1 c}$ was performed using HPLC, AUTO A1C (Kyoto Daiich Kagaku Co., Kyoto, Japan). The samples for the HPLC were prepared by using $0.9 \% \mathrm{NaCl}$ incubation to remove the labile aldimine fraction as mentioned before. The HPLC column used was the same one during all sample measurements. In this HPLC method, within-run precision (coefficient of variation, $\mathrm{CV}$ ) was $5.5 \%$, and between-run precision was $7.2 \%$.

\section{Statistical analysis}

Statistical significance was analysed by the Student's $t$-test.

\section{Results}

\section{Specificity of antiserum}

The characterization of the antiserum was studied in a competitive RIA in our previous paper $[10,11]$. The antiserum recognized glucitollysine. However, lysine, valine, mannitol and sorbitol were not recognized even when added in a large excess. Glucitolvaline was less than $1 \%$ cross-reactive when compared with glucitollysine. Reduced glycated $\mathrm{Hb}$ which was prepared from a diabetic patient was also recognized, and the shape of the inhibition curve was parallel with glucitollysine (Fig. 1). Non-reduced glycated $\mathrm{Hb}$ was not recognized even when added in a large excess. The binding of ${ }^{225}$ I-labelled native human albumin and ${ }^{125} \mathrm{I}$-labelled non-reduced glycated HSA to the antiserum were less than $1 \%$ of the total amount (data not shown). These results indicated that cross-reactivity to native HSA was eliminated from the antiserum preparation and that the dominant epitope recognized by the antiserum was identified as glucitollysine; the reduced hexose alcohol form of glucose conjugated to the $\varepsilon$-amino group of lysine. The antiserum was capable of identifying and quantitating glucitollysine residues on $\mathrm{Hb}$ after reduction with $\mathrm{NaBH}_{4}$.

For sample preparation we introduced TCA- $\mathrm{NaOH}$ treatment. Glucitollysine has been thought to be stable against acid like TCA $[12,19]$. In order to make sure of the stability of glucitollysine against $0.05 \mathrm{~N} \mathrm{NaOH}$ we compared the effect of treatment with $0.05 \mathrm{~N} \mathrm{NaOH}$ on a standard curve of glucitollysine, and we found no discernible difference between glucitollysine standards treated or not treated with $\mathrm{NaOH}$ (data not shown).

\section{Discrepancies of estimated reduced glycated $\mathrm{Hb}$ valued by RIA with or without TCA-NaOH treatment}

To investigate the effect of TCA-NaOH treatment, we assayed samples from two normal subjects and two diabetic patients, using the $\mathrm{TCA}-\mathrm{NaOH}$ treatment method and the dialysis method after reduction of the samples (Table 1). The values using our TCA-NaOH method were more than 20 -fold higher than the values using the dialysis method. Therefore, it is possible that TCA- $\mathrm{NaOH}$ treatment denatured $\mathrm{Hb}$, and exposed hidden glucitollysine epitopes.

\section{Linearity and precision of $R I A$}

To assess the linear range, we prepared a series of six solutions which were obtained from the glycated $\mathrm{Hb}$ fraction by using a Glyco-Gel B boronate affinity chromatography. All the samples were analysed four times by the RIA in different analytical batches (Fig.2). The plot of values was linear from 0.1 to as high as 6 nmol glucitollysine. Therefore, all samples were measured in this region.

Within-run precision (CV) assessed by five analyses of three specimens and between-run precision assessed by five analyses of three specimens, in separate analytical runs, over a three-week period was as shown in Table 2.

\section{Bio-Rex 70 chromatographic fractionation of $\mathrm{Hb}$}

In order to elucidate the localization of glucitollysine, we assayed all Bio-Rex 70 chromatographic fractions by our RIA. The chromatograms of Hbs from a normal subject and a diabetic subject are shown respectively in Figures 3 and 4. A large amount of glucitollysine was incorporated into the leading edge of the major $\mathrm{Hb}$ components $\left(\mathrm{HbA}_{0}\right)$ as reported by Bunn et al. [8]. Furthermore, it was clearly shown that the $\mathrm{HbA}_{i a+b}$ and $\mathrm{HbA}_{i c}$ peaks from the normal and diabetic subjects contained glucitollysine. It was therefore confirmed that $\mathrm{HbA}_{I c}$ is glycated not only at the $\beta$-amino terminus but also at the lysine $\varepsilon$-amino groups.

Table 1. Discrepancies in estimated reduced glycated $\mathrm{Hb}$ values by RIA with and without TCA-NaOH treatment

\begin{tabular}{llll}
\hline Sample & $\begin{array}{l}\mathrm{HbA}_{1 \mathrm{c}} \\
(\%)\end{array}$ & \multicolumn{2}{l}{$\begin{array}{l}\text { Glycated } \mathrm{Hb} \\
\text { (nmol glucitollysine/mg Hb) }\end{array}$} \\
\cline { 3 - 4 } & & Dialysis & TCA-NaOH \\
\hline 1 & 5.0 & 0.11 & 3.0 \\
2 & 5.2 & 0.12 & 3.2 \\
3 & 9.8 & 0.69 & 13.8 \\
4 & 11.0 & 0.75 & 16.7 \\
\hline
\end{tabular}

a TCA-NaOH was used instead of dialysis for the removal of excess $\mathrm{NaBH}_{4}$. The reduced glycated $\mathrm{Hb}$ was TCA precipitated and the precipitated protein was dissolved in $0.05 \mathrm{~N} \mathrm{NaOH}$ for analysis 


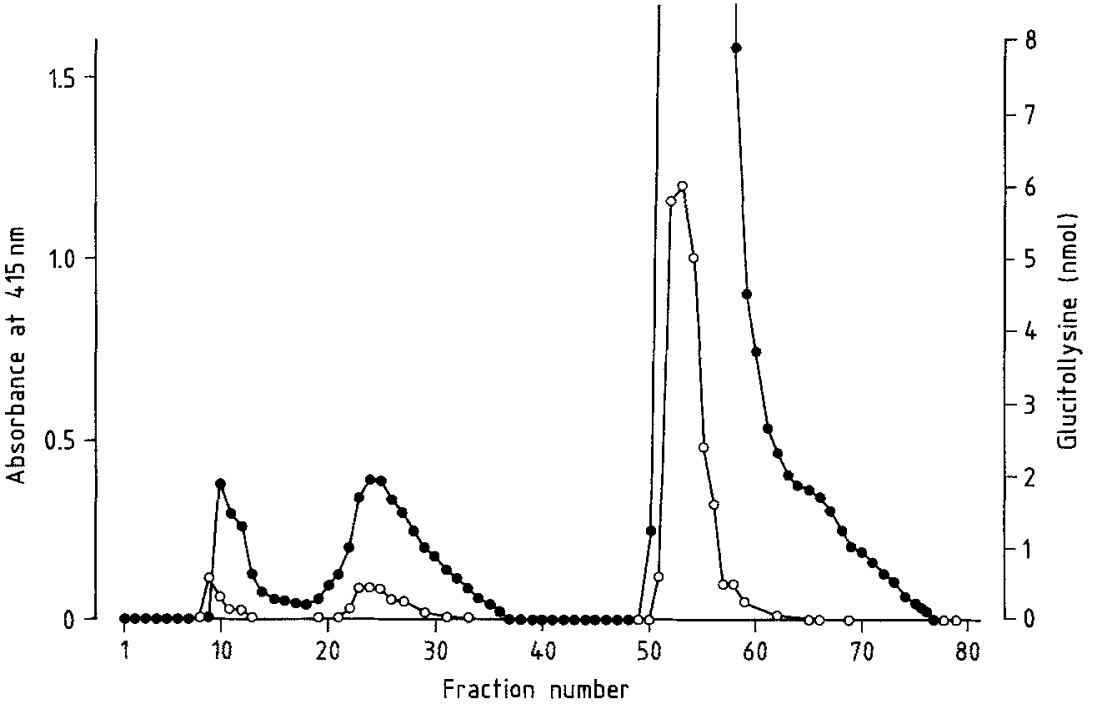

Fig.3. Bio-Rex 70 chromatographic separation of the Hbs in haemolysate from a normal adult. $300 \mu \mathrm{l}(25 \mathrm{mg})$ of haemolysate was applied to a column $(1 \times 30 \mathrm{~cm})$. Fraction size was $1.5 \mathrm{ml}$ and the flow rate was $15 \mathrm{ml} / \mathrm{h}$. At the point of fraction number 40 , stripping buffer was applied. (protein $(415 \mathrm{~nm}) ;(\mathrm{O}-\mathrm{O})$ glucitollysine (RIA)

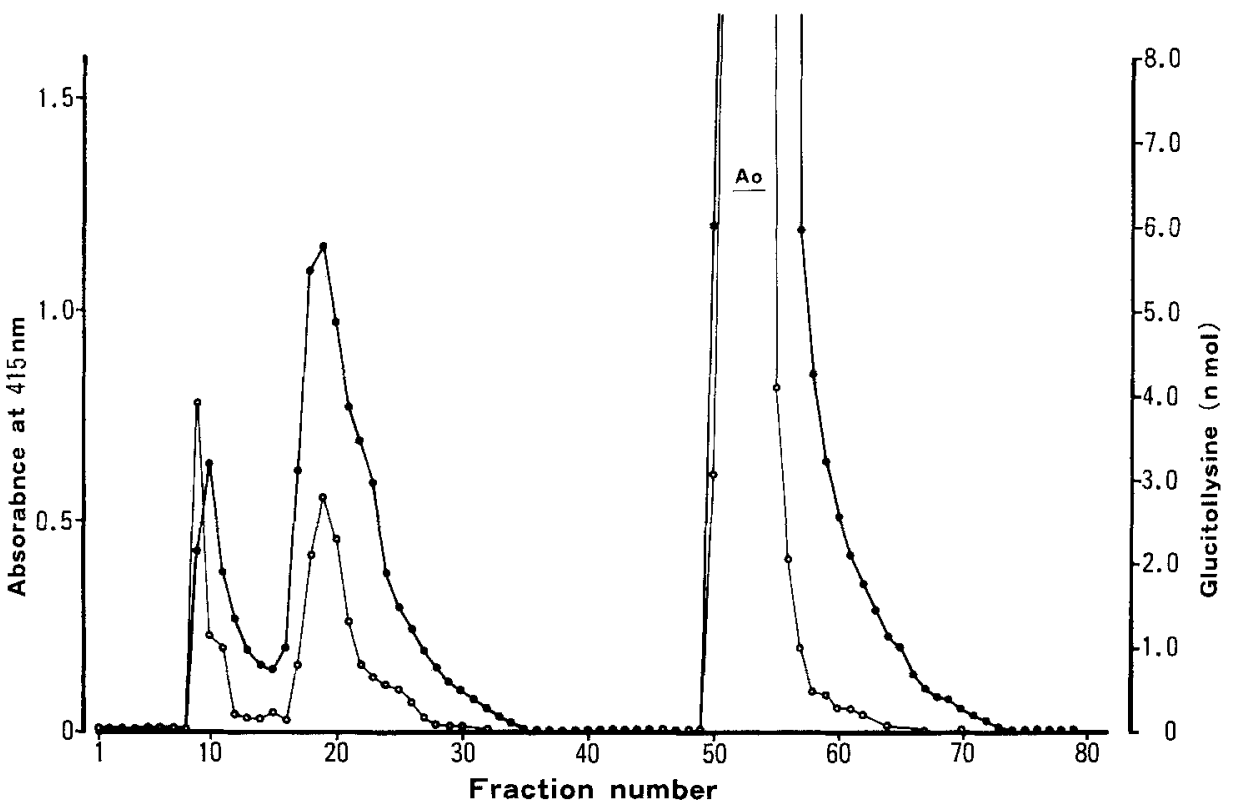

Fig.4. Bio-Rex 70 chromatographic separation of the $\mathrm{Hb}$ in a haemolysate from a diabetic patient. The details are those described in the legend to Figure 3 and in Materials and methods
Table 2. Precision of assay

\begin{tabular}{lccccc}
\hline Sample & \multicolumn{2}{c}{ Within-run $(n=5)$} & & \multicolumn{2}{c}{ Between-run $(n=5)$} \\
\cline { 2 - 3 } \cline { 5 - 6 } & Mean $\pm \mathrm{SD}^{\mathrm{a}} \mathrm{CV}(\%)$ & & Mean $\pm \mathrm{SD}^{\mathrm{a}} \mathrm{CV}(\%)$ \\
\hline 1 & $3.6 \pm 0.1$ & 2.8 & & $3.7 \pm 0.2$ & 5.4 \\
3 & $7.7 \pm 0.2$ & 2.6 & & $7.5 \pm 0.4$ & 5.3 \\
\hline
\end{tabular}

$\overline{{ }^{a} \text { nmol glucitollysine/mg } \mathrm{Hb}}$

\section{Comparison of glycated Hb by RIA with HPLC}

The results of assays for glycated $\mathrm{Hb}$, carried out on the $\mathrm{N}$, IGT and diabetic subjects, are presented in Figure 5. The mean glycated $\mathrm{Hb}$ levels by RIA were $3.3 \pm 0.4 \mathrm{nmol}$ glucitollysine/mgHb (mean $\pm \mathrm{SD}$ ) in $\mathrm{N}, 4.7 \pm 0.5$ in IGT and $14.4 \pm 7.5$ in the diabetic group. The differences between the three groups were highly significant $(p<0.001)$. On the other hand, the mean $\mathrm{HbA}_{1 c}$ levels by HPLC were
$\mathrm{N}: 5.0 \pm 0.4 \%$ (mean \pm SD), IGT: $5.1 \pm 0.3 \%$, and there was no significant difference between the $\mathrm{N}$ group and IGT group. Fifteen of the 20 IGT patients exceeded the upper normal range (mean normal values $+2 \mathrm{SD}$ ) for RIA values. But all IGT patients were within the upper normal range for $\mathrm{HbA}_{1 c}$ values.

\section{Discussion}

It has been generally accepted that the level of glycated $\mathrm{Hb}$ is a clinically useful measure of the average long-term glycaemic control in a diabetic patient. While the development of a quantitative methodology for the measurement of glycated $\mathrm{Hb}$ has been extensively carried out, there is still a need for better methods of measurement with appropriate references and standards with which accuracy and precision can be maintained. Recently, the National Diabetes Data Group in the United States has concluded that a major problem with all methods is that there are no agreed upon references and standards [6]. 


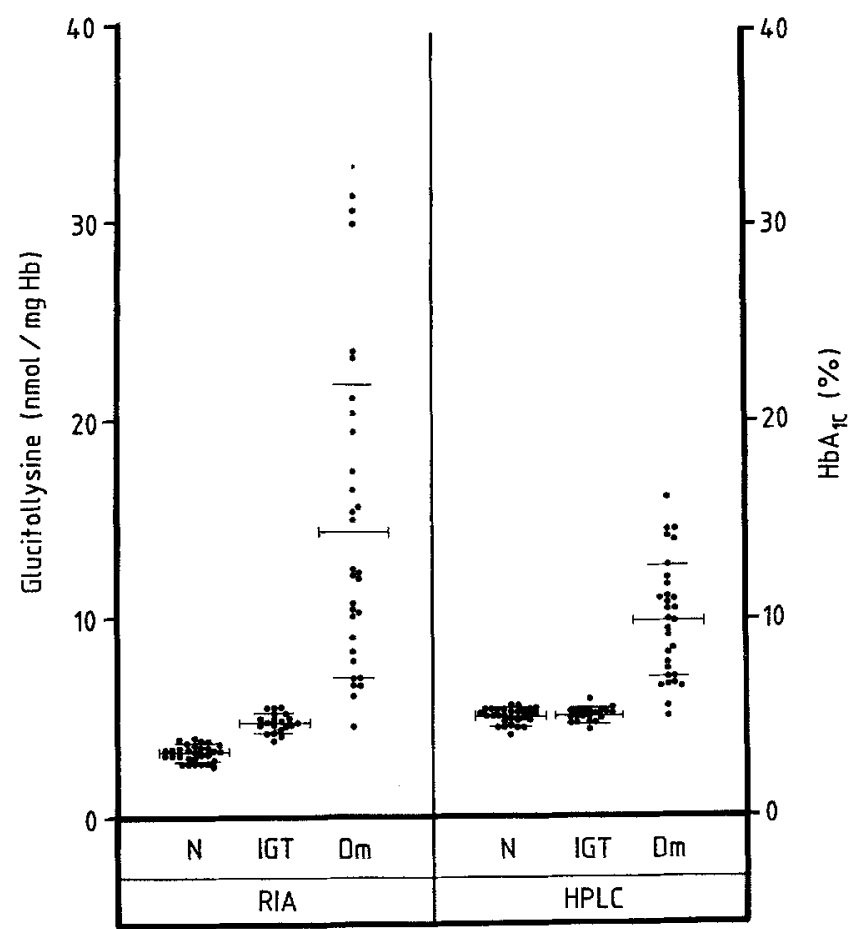

Fig.5. Glycated $\mathrm{Hb}$ levels in normal $(\mathrm{N})(n=30)$, impaired glucose tolerance $(\operatorname{IGT})(n=20)$, and diabetes mellitus $(\mathrm{Dm})(n=30)$, determined by RIA and HPLC. The horizontal lines indicate the mean \pm SD of each group. Mean values significantly different in RIA: N vs IGT $(p<0.001)$; IGT vs Dm $(p<0.001)$. Mean values significantly different in HPLC: N vs IGT (NS); IGT vs Dm $(p<0.001)$

The RIA method presented in this report has the advantage of using glucitollysine which is chemically stable. Shapiro et al. found that sites of $\mathrm{Hb}$ glycation were different in vitro and in vivo [9], so if glycated $\mathrm{Hb}$ was synthesized in vitro as a standard, it is chemically different from $\mathrm{Hb}$ glycated in vivo. On the other hand, glucitollysine was easily synthesized and was resistant to acidic and alkaline conditions $[12,19]$. Since our RIA method used glucitollysine as a standard substance, this method has a chemically defined and stable reference standard.

In the sample preparation, it was necessary to reduce glycated $\mathrm{Hb}$. After reduction, dialysis or gel filtration was generally used to stop the reduction and to remove unreacted $\mathrm{NaBH}_{4}[8,20]$. Since this is too time consuming for routine use we introduced the TCA-NaOH treatment after reduction as has been described previously [10]. By using the TCA-NaOH treatment, the assay was relatively simple. Moreover, the TCA-NaOH treatment seemed to have another advantage in that it offered greater sensitivity (Table 1). A possible explanation for this increased sensitivity has been reported in a study of murine monoclonal antibodies recognizing glucitollysine [20]. Utilizing this monoclonal antibody, the levels of glucitollysine quantitated were lower than previous estimates of the amount of glucose bound to total plasma proteins and it was though that the presence of hidden glucitollysine epitopes not accessible to the antibodies could account for the difference. As shown in Table 1, the values determined by TCA$\mathrm{NaOH}$ treatment were about 25 times higher than those by dialysis. The amount of glucose assayed RIA as bound to
$\mathrm{Hb}$ in TCA-NaOH treated samples was similar to previous estimates by the HPLCanalysis of furosine, a specificquantitation of $\varepsilon$-amino group lysine-bound glucose in $\mathrm{Hb}$ $[21,22]$. Moreover, the synthesized reduced glycated $\mathrm{Hb}$ contained $35 \%$ of the lysine residues. Thus, 15 moles of 44 moles of lysine residues were glycated as determined by amino acid analysis which is equivalent to about $200 \mathrm{nmol}$ glucitollysine $/ \mathrm{mgHb}$. This value was similar to the $178 \mathrm{nmol}$ glucitollysine/mgHb which was measured using the RIA with TCA-NaOH treatment. By contrast, the dialysis method revealed a far lower value of $7.0 \mathrm{nmol}$ glucitollysine $/ \mathrm{mgHb}$. Thus, it is plausible that the increased values found following TCA-NaOH treatment in comparison with the dialysis method for sample preparation is a consequence of the unfolding of the $\mathrm{Hb}$ molecule, thereby exposing the hidden glucitollysine epitopes.

It has been shown previously that glucose is conjugated to the $\varepsilon$-amino group of lysine of $\mathrm{Hb}$ which exists in the $\mathrm{HbA}_{0}[8,21]$. We are able to clearly demonstrate that glucose conjugated to the $\varepsilon$-amino group of $\mathrm{Hb}$ exists not only in the $\mathrm{HbA}_{0}$ but also in the $\mathrm{HbA}_{1 c}$ (Figs. 3 and 4).

The diagnostic value of the RIA method and the HPLC method was compared in the N, IGT, and diabetes groups. $\mathrm{HbA}_{I c}$ as determined by HPLC could clearly separate a group of $\mathrm{N}$ from a group of diabetic patients, but could not separate a group of $\mathrm{N}$ from a group of IGT. On the other hand, by the RIA method there was a significant difference between the groups of $\mathrm{N}$ and IGT. Moreover, all of the 20 IGT patients were within the upper normal range for $\mathrm{HbA}_{l c}$ by the HPLC method, but 15 of the 20 IGT patients exceeded the upper normal range for our RIA method. Thus the RIA method might be able to be used to detect IGT patients in a mass screening test.

A quantitative ELISA for glycated serum albumin by using the same antiserum [10] was recently developed in our laboratory and the RIA method seems to be applicable to quantitate any kind of glycated protein with the desired precision for clinical use [11] (Table 2).

Acknowledgments. We are grateful to Drs. E. Rayfield and R. Bucala for helpful discussions.

\section{References}

1. Koenig RJ, Blobstein SH, Cerami A (1977) Structure of carbohydrate of hemoglobin $A_{I c}$. J Biol Chem 252: 2992-2997

2. Nathan DM, Singer DE, Hurxthal K, Goodson JD (1984) The clinical information value of the glycosylated hemoglobin assay. N Engl J Med 310: 341-346

3. Jovanovic L, Peterson CM (1981) The clinical utility of glycosylated hemoglobin. Am J Med 70: 331-338

4. Bunn HF (1981) Nonenzymatic glycosylation of protein: relevance to diabetes. Am J Med 70: 325-330

5. Goldstein DE, Little PR, Wiedmeyer HM, England JD, Mckenzie E (1986) Glycated hemoglobin: methodologies and clinical applications. Clin Chem 32: B64-B70

6. Baynes NW, Burn HF, Goldstein D, Harris M, Martin DB, Peterson CM, Winterhalter K (1984) National Diabetes Data Group: report of the expert committee on glycosyated hemoglobin. Diabetes Care 7: 602-607

7. Peterson CM, Formby B (1985) Glycosylated proteins. In: Alberti KGMM, Krall LP (eds) The Diabetes Annual, 1. Elsevier, Amsterdam, pp 178-197 
8. Bunn HF, Shapiro R, McManus M, Garrick L, McDonald MJ, Gallop PM, Gabbay KM (1979) Structural heterogeneity of human hemoglobin A due to nonenzymatic glycosylation. J Biol Chem 254: 3892-3898

9. Shapiro R, McManus MJ, Zalut C, Bunn HF (1980) Sites of nonenzymatic glycosylation of human hemoglobin A. J Biol Chem 255:3120-3127

10. Nakayama H, Makita Z, Kato M, Taneda S, Yoshida H, Yanagisawa K, Nakagawa S (1987) Quantitative enzyme-linked immunosorbent assay (ELISA) for non-enzymatically glycated serum protein. J Immunol Methods 99: 95-100

11. Nakayama H, Taneda S, Manda N, Aoki S, Komori K, Kuroda Y, Misawa K, Tsushima S, Nakagawa S (1986) Radioimmunoassay for nonenzymatically glycated protein in human serum. Clin Chim Acta 158: 293-299

12. Trüeb B, Hughes GJ, Winterhalter KH (1982) Synthesis and quantitation of glucitollysine: a glucosylated amino acid elevated in proteins from diabetics. Anal Biochem 119:330-334

13. Schwartz BA, Gray GR (1977) Proteins containing reductively aminated disaccharides. Arch Biochem Biophys 181: 542-549

14. Nathan DM, Avezzano ES, Palmer JL (1981) A rapid chemical means for removing labile glycohemoglobin. Diabetes 30: 700701

15. Abraham EC, Huff TA, Cope ND, Wilson JB, Bransome ED, Augusta DS (1982) Determination of the glycosylated hemoglobins $\left(\mathrm{HbA}_{1 c}\right)$ with a new microcolumn procedure. Diabetes 27 : 931-937

16. WHO Expert Committee on Diabetes Mellitus (1980) Second Report. Geneva. World Health Organization (Tech. Rep. Ser. 646)

17. Nakayama H, Manda N, Komori K, Aoki S, Ono Y, Makita Z, Nakagawa S (1982) Studies on the determination of glucosylated albumin using affinity chromatography. J Jpn Diabetes Soc 25: 963-968

18. Lowry O, Rosebrough NJ, Farr AI, Randall RJ (1951) Protein measurement with the Folin phenol reagent. J Biol Chem 193: 265-275

19. Ma A, Naughton MA, Cameron DP (1981) Glucosylated plasma protein: a simple method for the elimination of interference by glucose in its estimation. Clin Chem Acta 115: 111-117

20. Curtiss LK, Witzum JL (1983) A novel method for generating region-specific monoclonal antibodies to modified proteins. J Clin Invest 72: 1427-1438

21. Schleicher E, Scheller L, Wieland OH (1981) Quantitation of lysine-bound glucose of normal and diabetic erythrocyte membranes by HPLC analysis of furosine. Biochem Biophys Res Commun 99: 1011-1019

22. Schleicher E, Wieland OH (1986) Kinetic analysis of glycation as a tool for assessing the half-life of proteins. Biochim Biophys Acta 884: 199-205

Received: 30 March 1990

and in revised form: 24 July 1990

Dr. Z.Makita

The Second

Department of Medicine,

Hokkaido University

School of Medicine

Kita 15, Nishi 7,

Kita-Ku,

Sapporo

Japan 